ex Instituto Archaeologico Universitatis de Rolando Eötvös nominatae

C

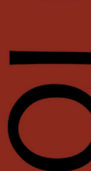

ப

$\varangle$

工

$\cup$

ه

$<$

in

ㄴ
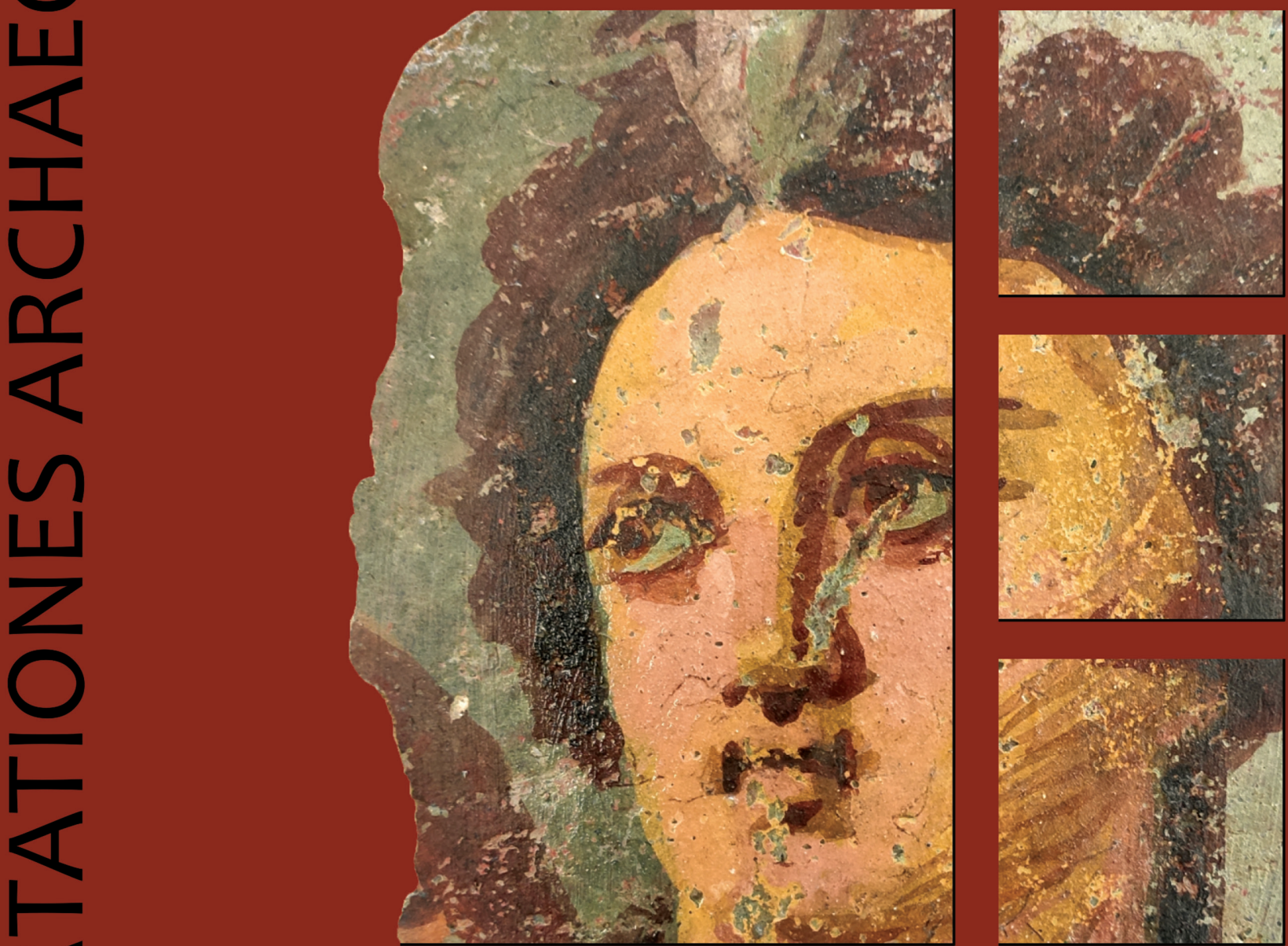

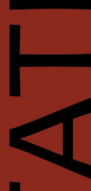

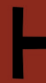

ח

Ш

un

n

0
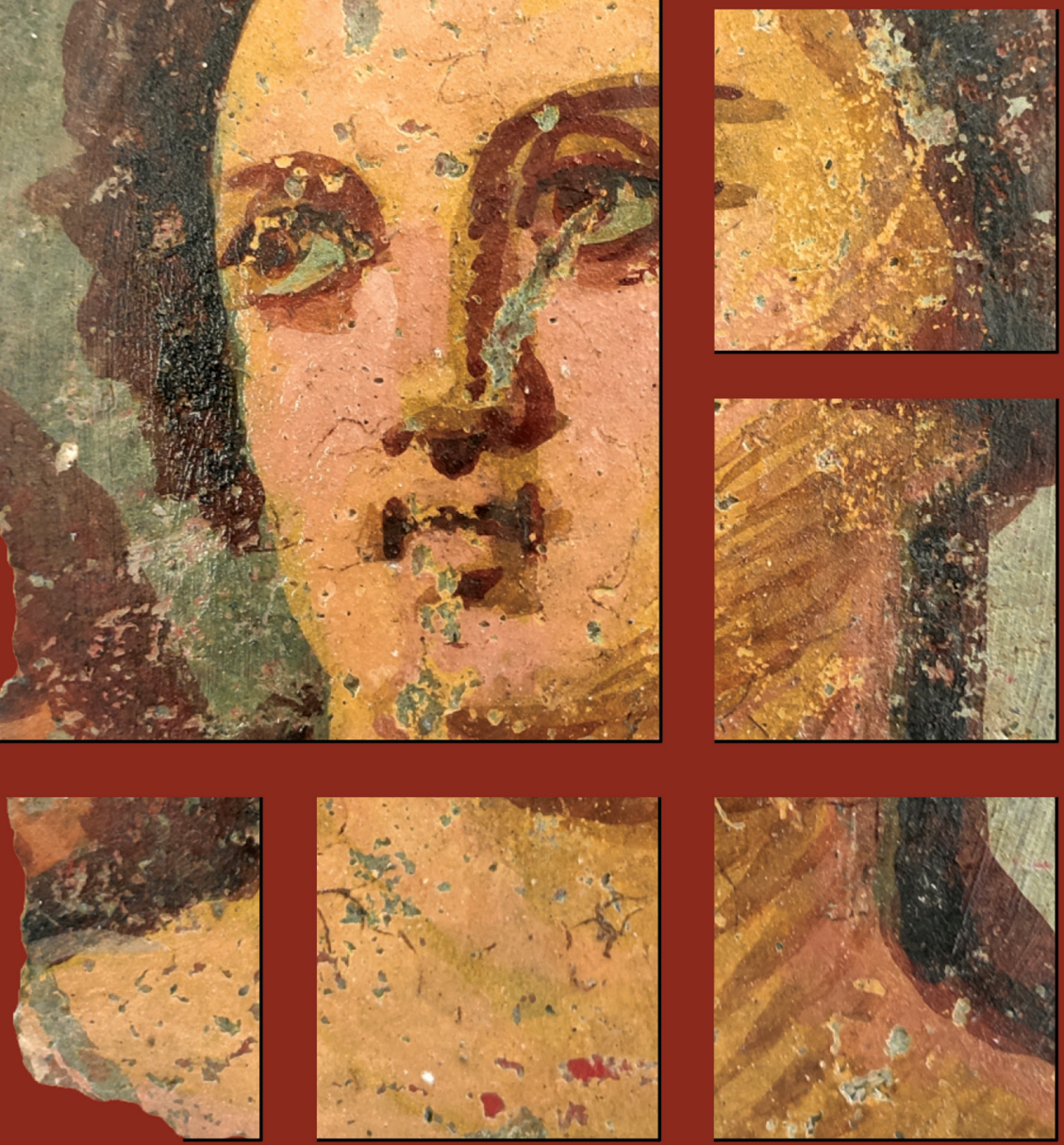

Serp 30 No. 8. 2020 


\section{Dissertationes Archaeologicae ex Instituto Archaeologico}

Universitatis de Rolando Eötvös nominatae Ser. 3. No. 8.

Budapest 2020 
Dissertationes Archaeologicae ex Instituto Archaeologico Universitatis de Rolando Eötvös nominatae Ser. 3. No. 8.

Editor-in-chief:

DÁvid Bartus

Editorial board:

LÁsZló BARTOSIEWICZ

LÁsZLÓ BORHY

ZOLTÁN CZAJLIK

IsTVÁN FELD

GÁBOR KALLA

PÁL RACZKY

MiKLÓS SZABÓ

Tivadar Vida

Technical editor:

Gábor VÁczi

Proofreading:

Szilvia BARTUS-SzÖLLŐsI

Zsófia KondÉ

Márton SZILÁGYI

Aviable online at http://ojs.elte.hu/dissarch

Contact: dissarch@btk.elte.hu

ISSN 2064-4574

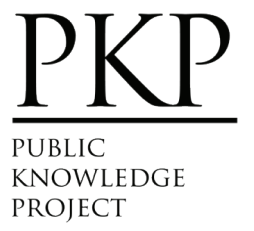

๑ ELTE Eötvös Loránd University, Institute of Archaeological Sciences

Layout and cover design: Gábor Váczi

Budapest 2020 


\section{CONTENTS}

\section{ARTICLES}

Maciej WAWRZCZAK - Zuzana KASENČÁKovÁ

Stará L'ubovña - Lesopark. Late Palaeolithic site and the problems associated with raw material mining

Attila PÉNTEK - Norbert FARAgó

Chipped stone assemblages from Schleswig-Holstein (North Germany) in the collection of the Institute of Archaeological Sciences - ELTE Eötvös Loránd University

Bence Soós 49

Middle Iron Age Cemetery from Alsónyék, Hungary

Tamás Szeniczey - Tamás Hajdu 107

Appendix - Results of the analysis of the Early Iron Age human remains unearthed at Alsónyék, Hungary

Lajos JuHÁsz - József Géza Kiss

Bound in bronze - a Roman bronze statuette of a barbarian prisoner

Csilla SÁRó

The fibula production of Brigetio: clay moulds

\section{Field Reports}

András Füzesi - Knut Rassmann - Eszter BÁnffy - Hajo Hoehler-Brockmann -

Gábor Kalla - Nóra Szabó - Márton SzIlágyi - Pál Raczky

Test excavation of the "pseudo-ditch" system of the Late Neolithic settlement complex at Öcsöd-Kováshalom on the Great Hungarian Plain

Gábor VÁczi - László RupNIK - Zoltán CZAJLIK - Gábor MEsterházy Bettina BitTner - Kristóf FÜlöP - Denisa M. LÖNHARdT - Nóra Szabó

The results of a non-destructive site exploration and a rescue excavation at the site of Pusztaszabolcs-Dohányos völgy északi part

Dávid BArtus - László Borhy - Szilvia JohÁczi - Emese SzÁmadó 181

Excavations in the legionary fortress of Brigetio in 2019 
Dávid BArtus - László Borhy - Emese SzÁmadó - Lajos Juhász - Bence Simon -

Ferenc Barna - Anita Benes - Szilvia Joháczi - Rita Olasz - Melinda Szabó

Excavations in Brigetio in 2020

\section{Thesis Abstracts}

Anett OszTÁs

The settlement history of Alsónyék-Bátaszék.

Complex analysis of its buildings in the context of the Lengyel culture

Csilla SzÁRAz

The region of the Zala and Mura Rivers (Zala County) in the Late Bronze Age.

Late Tumulus and Urnfield period

Ágnes KIRÁly

Human remains unearthed in settlement context from the Late Bronze Age -

Early Iron Age (Reinecke BD-HaB3) Northeastern Hungary

Gergely BóKA

Transformation of settlement history in the Körös Region in the period between the Late Bronze Age and the end of Iron Age

Gabriella G. DeLbó

Pottery production of the settlement complex of Brigetio

Adrienn Katalin BLAY

Die Beziehungen zwischen dem Karpatenbecken und dem Mediterraneum

von der II. Hälfte des 6. bis zum 8. Jahrhundert n. Chr. anhand Schmuckstücken

und Kleidungszubehör

Levente SAMU

293

Die mediterranen Kontakte des Karpatenbeckens in der Früh- und Mittel-

awarenzeit im Licht der Männerkleidung. Gürtelschnallen und Gürtelgarnituren

\section{REviEWS}

Gábor MESTERHÁZY

Czajlik, Z. - Črešnar, M. - Doneus, M. - Fera, M. - Hellmith Kramberger, A. Mele, M. (eds): Researching Archaelogical Landscapes Across Borders - Strategies,

Methods and Decisions for the 21th Century. Graz-Budapest, 2019. 


\title{
Excavations in the legionary fortress of Brigetio in 2019
}

\author{
Dávid BARTus
}

Institute of Archaeological Sciences

ELTE Eötvös Loránd University

bartus.david@btk.elte.hu

Szilvia JoHÁczI

Institute of Archaeological Sciences

ELTE Eötvös Loránd University

johisziszi@gmail.com

\author{
László BORHY \\ Institute of Archaeological Sciences \\ ELTE Eötvös Loránd University \\ borhy.laszlo@btk.elte.hu
}

Emese SzÁMADÓ

Komáromi Klapka György Museum

Komárom

emese@kgym.hu

\begin{abstract}
In 2019 the excavations in Brigetio focused on the area of the northern gate of the legionary fortress, as the geophysical surveys conducted in the previous year allowed the identification of both the porta praetoria and the via praetoria leading through it. These fieldworks, beside providing new information on the topography of the legionary fortress regarding the porta praetoria and the via praetoria, were also significant from a methodological point of view as they allowed the verification of the results of geophysical surveys conducted in the area earlier, thus contributing greatly to the planning and fine-tuning of future measurements.
\end{abstract}

Excavations have been carried out regularly since 2015 in the territory of the legionary fortress of Brigetio, including investigations in the area of the principia as well as the eastern part of the praetentura. ${ }^{1}$ In 2015 we located the courtyard of the principia and details of buildings situated south of it, as well as a section of the road separating the principia and the barracks of cohors I. In 2017 and 2018 we excavated a large-sized apsidal building near the porta principalis dextra in the southeastern corner of the praetentura. The construction of this aula type building can be dated around the 370s and presumably it was the venue where Valentinian I received the envoys of the Quadi on 17th November 375, as a result of which he eventually suffered a stroke and died. Several rooms belonging to earlier construction phases have been unearthed below the building. ${ }^{2}$

In 2019 the excavations focused on the area of the northern gate of the legionary fortress, as the geophysical surveys conducted in the previous year allowed the identification of both the porta praetoria and the via praetoria leading through it (Fig. 1).

Thus, beyond its traditional scientific goals the excavation was of great significance also from a methodologial point of view, as it provided us with the possibility to verify the results of the GPR-survey, which may proove useful in the preparation and fine-tuning of further surveys.

1 For a summary of the excavations in the legionary fortress of Brigetio see BARTus et al. 2016; BARTUS et al. 2018b.

2 BARTus et al. 2018a. 


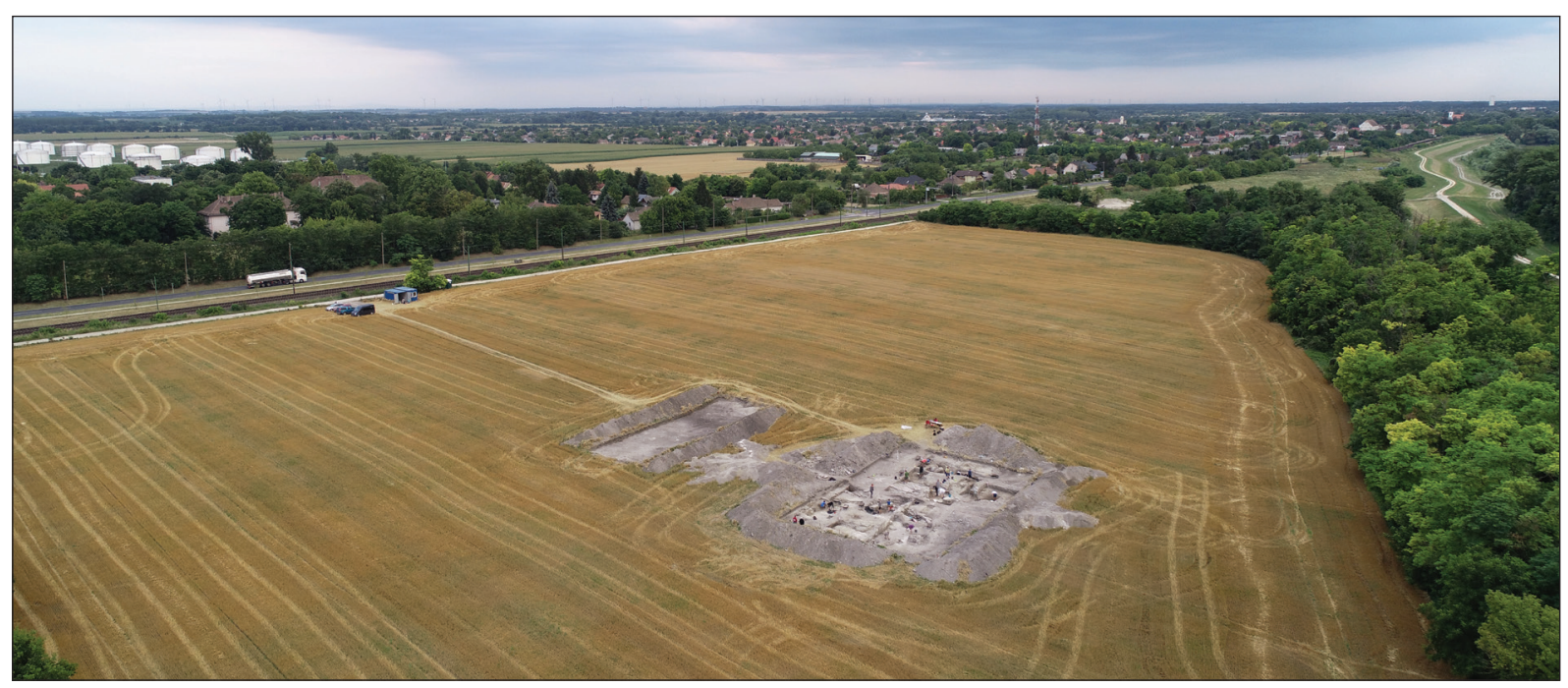

Fig. 1. The praetentura of the legionary fortress of Brigetio with the excavated surfaces (Photo: D. Bartus).

The first excavated location has been the northern main gate of the legionary fortress, the porta praetoria. In this area there already was a small-scale excavation in 1941 led by Aladár Radnóti during which a section of the gate towers were unearthed, however the excavation's documentation has gone completely lost. ${ }^{3}$

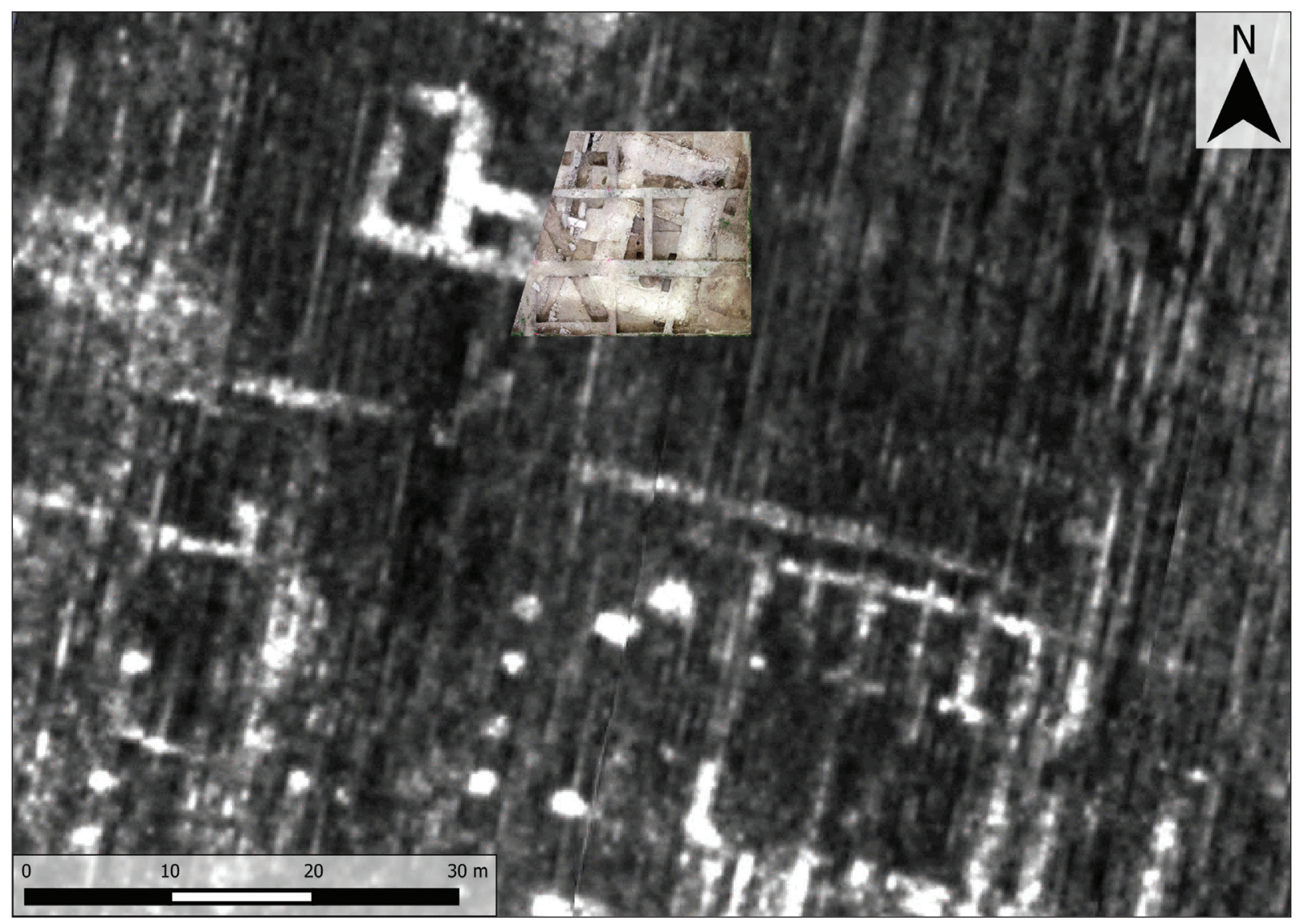

Fig. 2. Hybrid image of the porta praetoria: the GPR survey before the excavation, and aerial photo of the unearthed eastern tower (L. Rupnik - B. Simon - D. Bartus).

3 BARKóCZI 1951, 14. 
Our excavation has confirmed the results of the geophysical measurements (Fig. 2): the gate of the porta praetoria consisted of two rectangular gate towers with considerably massive stone foundations, however only a few stone blocks of the rising walls have remained in place (Fig. 3). Thus, we only have limited knowledge of the inner structure of the towers; we could identify the traces of a later reconstruction in the western tower while in the eastern tower we discovered a massive chalky layer which could be related to a reconstruction or possibly the demolition of the tower.

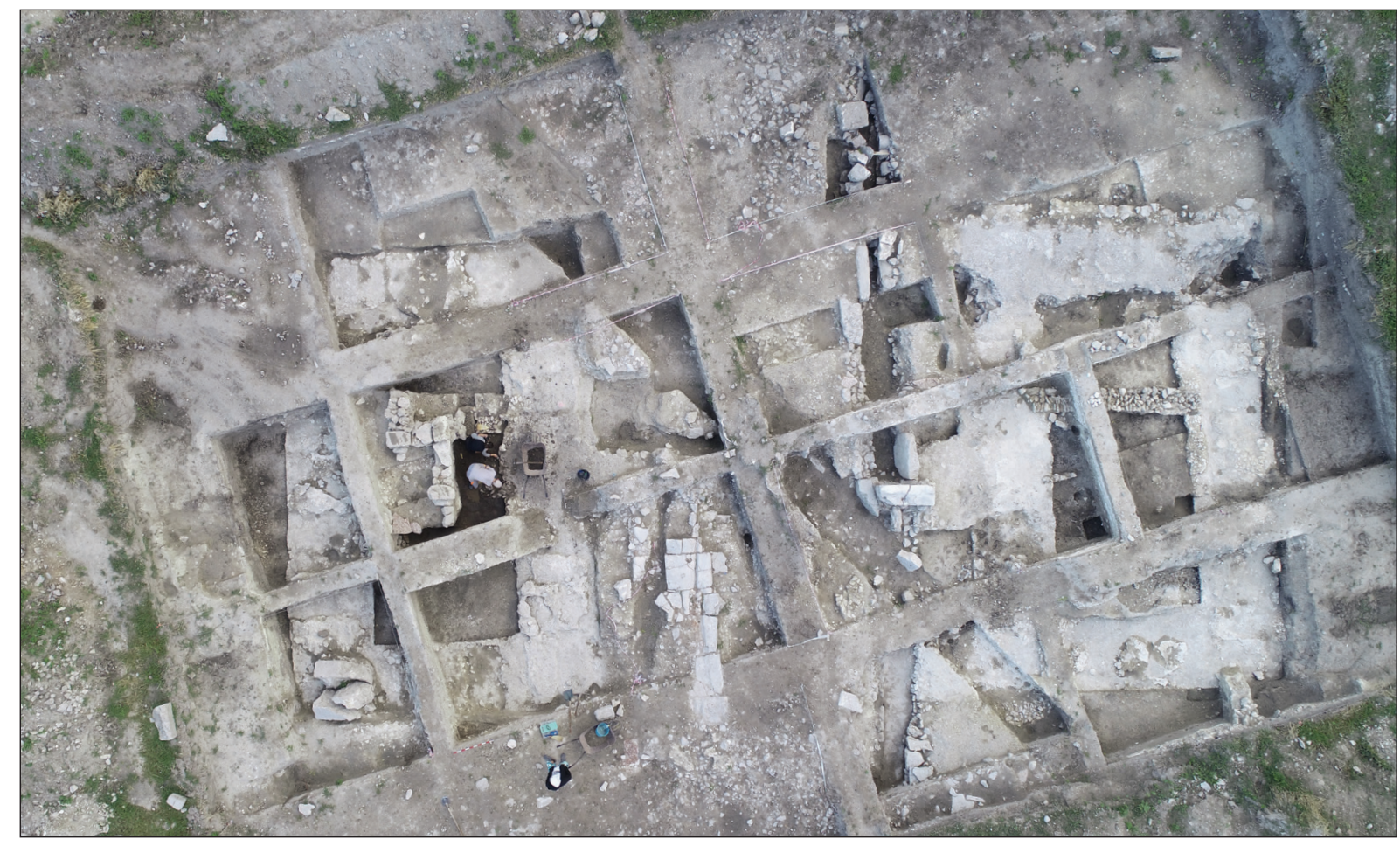

Fig. 3. The porta praetoria during the excavation (Photo: D. Bartus).

The dismantling of the towers could have been carried out already in Roman times, it is concievable that the gate has no longer been used during the late Roman period. The size $(8 \times 12 \mathrm{~m})$ and the layout of the towers can be considered common in Roman military architecture. They belong among the type of towers protruding inward, of which numerous examples are known from other legionary fortresses. ${ }^{4}$

The via praetoria passed through the gateway between the two towers (Fig. 4). It was covered with large stone slabs on which the ruts of cartwheels were clearly observable (Fig. 5). Inside the gateway no traces of a possible double-portalled gate could be documented, therefore the assumption of previous research regarding a single-portalled gate can be further maintained.

The stones comprising the fortress walls have been - similarly to other areas within Brigetio plundered in modern times, therefore the walls once connecting to the porta praetoria could only be identified in the form of trenches. The turf rampart running along the inner side of the wall was clearly observable on the eastern side of the gate. ${ }^{5}$

4 BISHop 2012, Fig. 29, 32, 35, 47, etc. On the gates of Roman legionary fortresses in general, see BECHERT 1971. On the porta praetoria in general, see AumüLlER 2002, 231-304.

5 BARKóczi 1951, 15. 


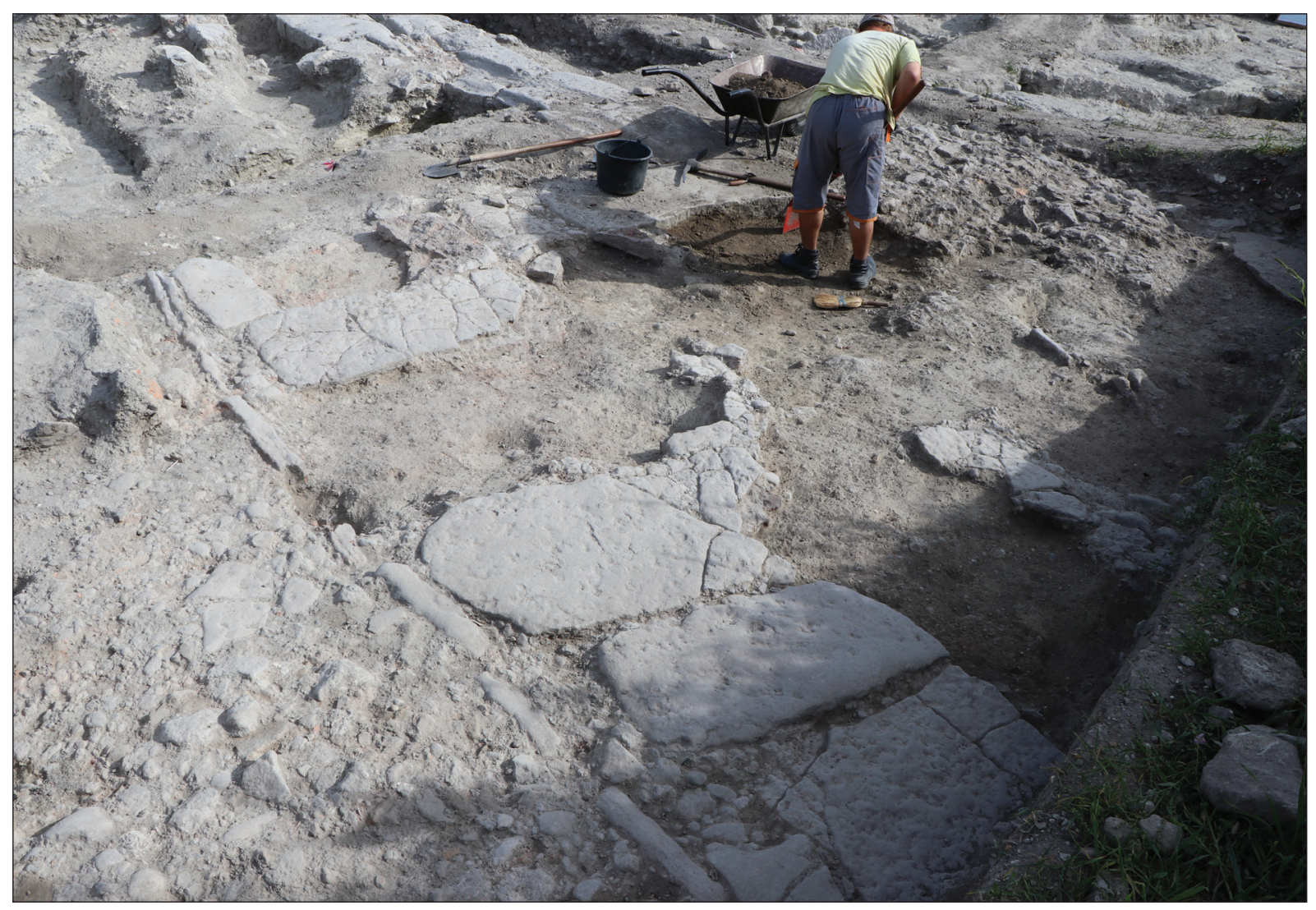

Fig. 4. Stone slabs covering the via praetoria (Photo: D. Bartus).

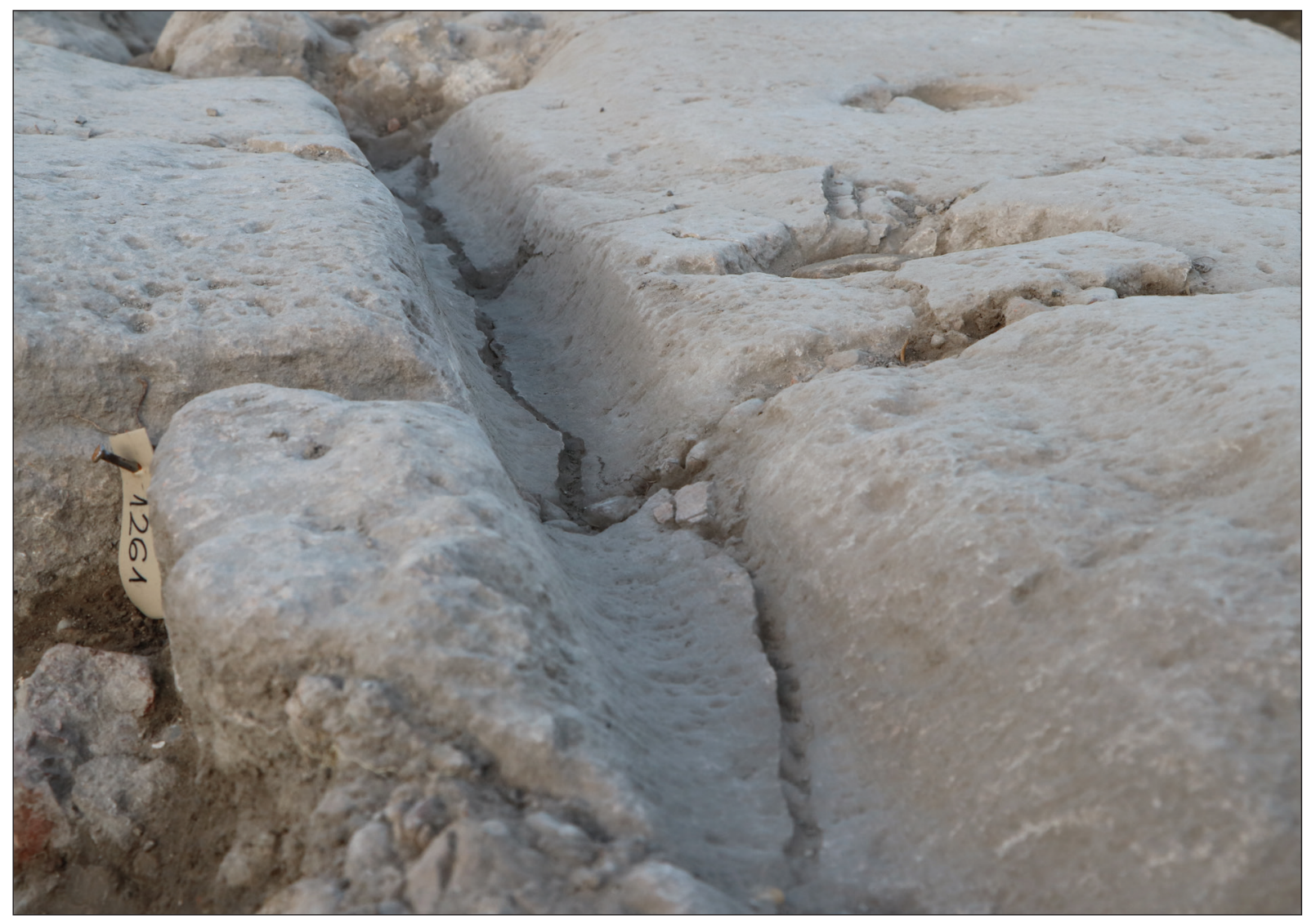

Fig. 5. Ruts of cartwheels in the gateway (Photo: D. Bartus). 
Dating is considerably difficult due to the fact that the gate towers have most probably been dismantled already in the Roman period. Also, the excavation of 1941 as well as drainage construction works in the 1950s have significantly disturbed the environment of the gate. As a result, we could not gain accurate information during the excavation regarding to the construction or periodisation of the gate; hopefully the evaluation of the find material will contribute to a more precise picture.

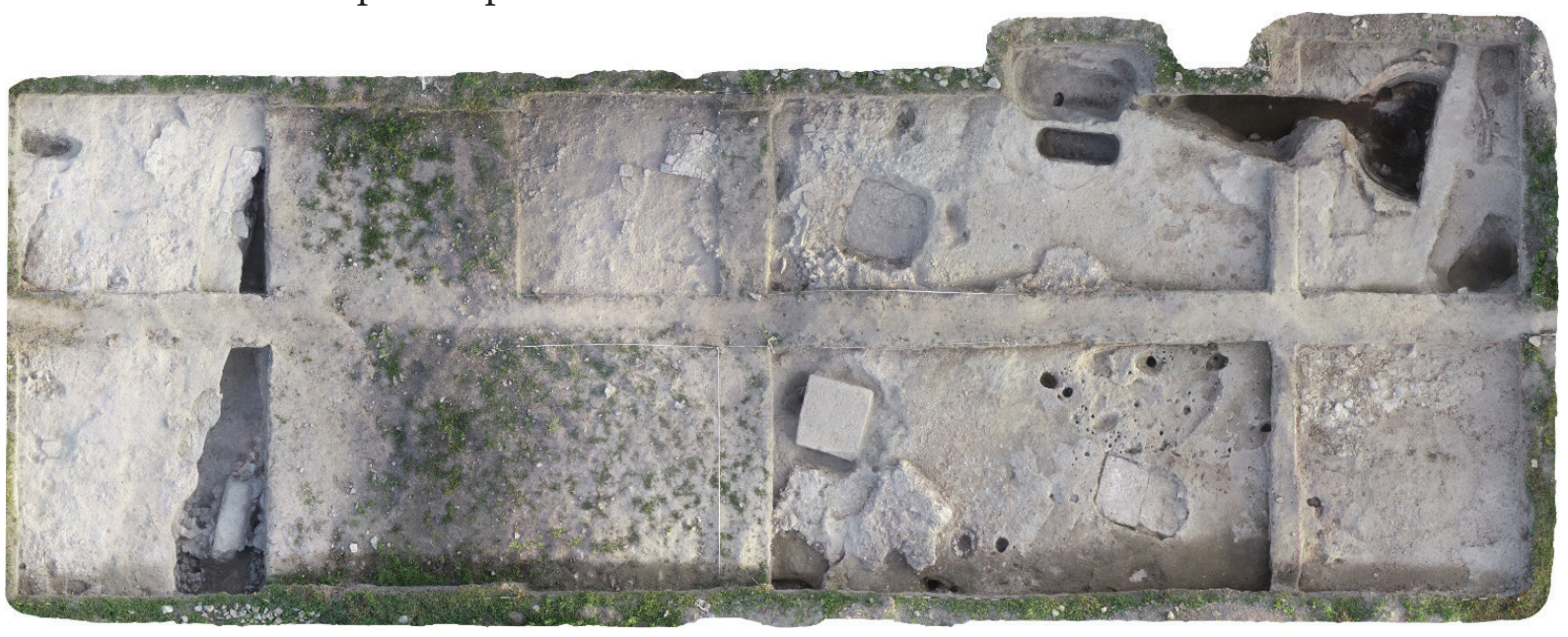

Fig. 6. Ortophoto of the southern excavation surface with pillar bases flanking the via praetoria (B. Simon).

The second excavated location was situated slightly to the south of the porta praetoria, along the via praetoria. Only a few stone slabs covering the main road of the legionary fortress remained in their original place, however we have excavated four pillar bases belonging to the row of pillars flanking the via praetoria (Fig. 6), which were also clearly visible on the GPR images. East of the main road we have unearthed a late Roman lime kiln (Fig. 7), which had been

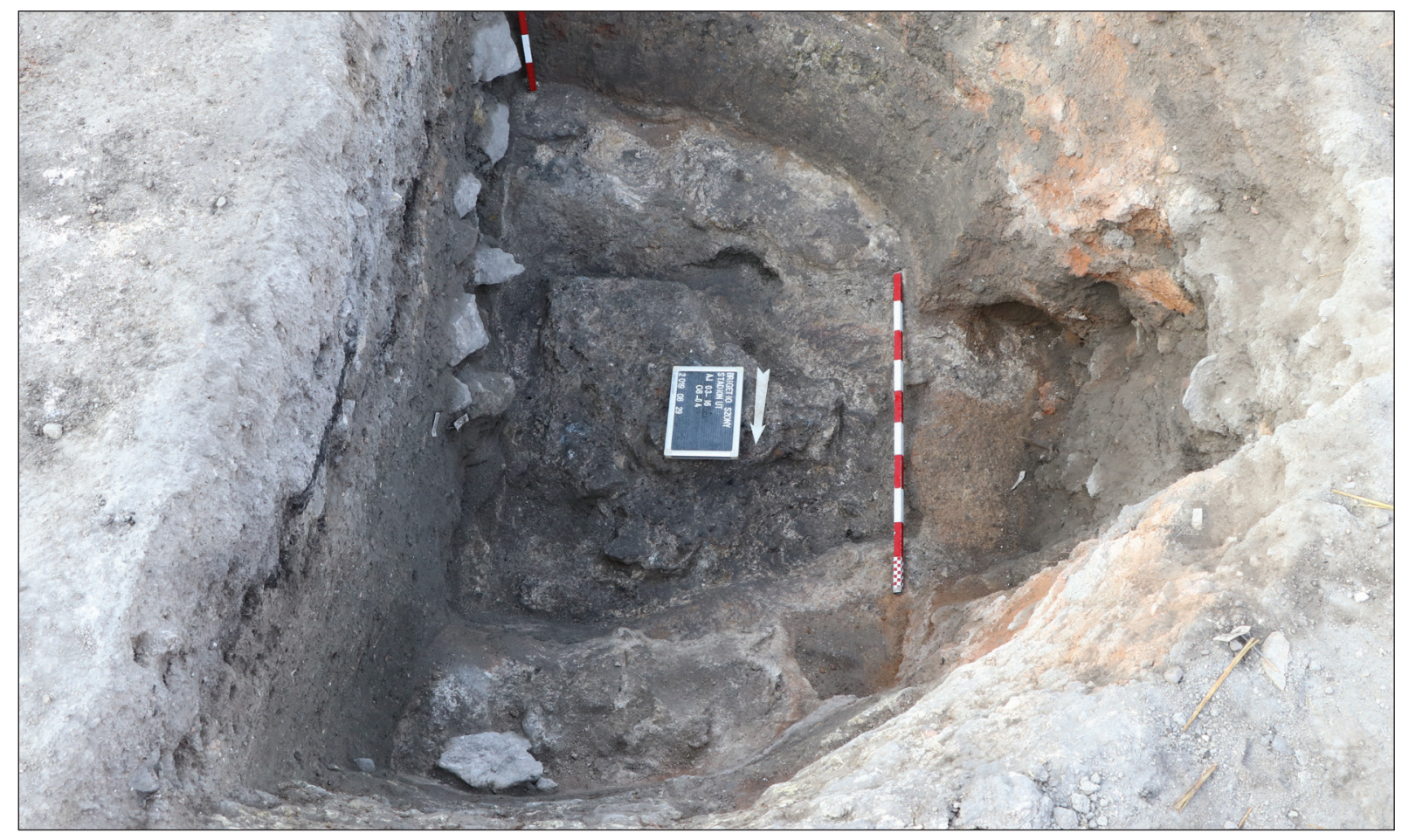

Fig. 7. The Late Roman lime kiln (Photo: D. Bartus). 


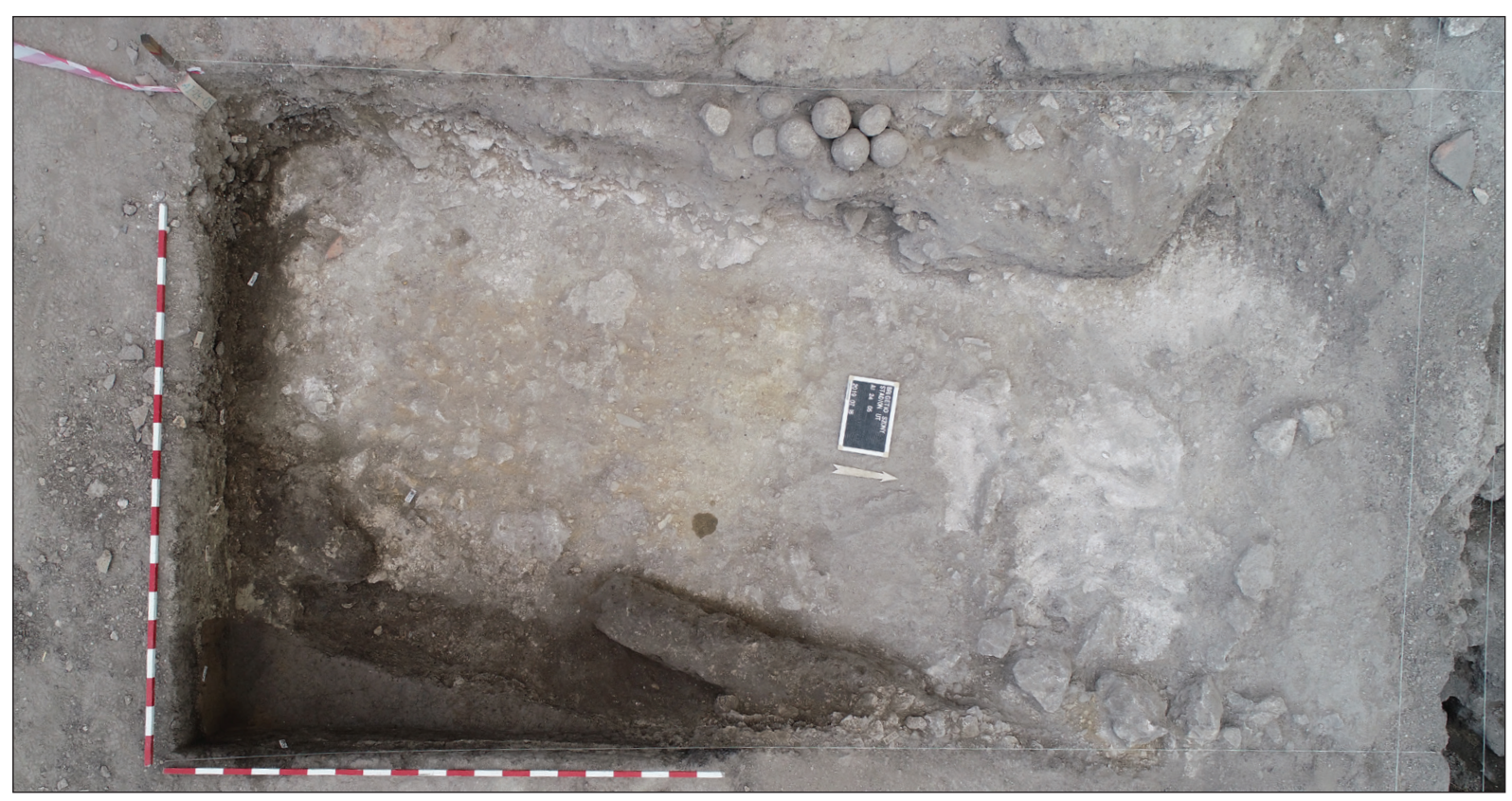

Fig. 8. Stone balls from the eastern tower in situ (Photo: D. Bartus).

filled with debris and litter after being abandoned. From the upper levels of its filling more than a hundred roman coins came to light. A few metres to the west of the lime kiln two Migration Period graves represented the period following the abandonment of the legionary fortress.

More than a dozen stone balls came to light from the eastern gate tower which can be identified as ammunition for a stone projector (Fig. 8), therefore, from the find material's point of view, they are related to the primary function of the fortress. ${ }^{6}$ The caliga nails found in their original position beside the gate can also be linked to the military (Fig. 9). Perhaps the bronze statuette representing a murmillo gladiator in fine detail, found in the trench flanking the via praetoria has also been among the personal belongings of a soldier. ${ }^{7}$

The 2019 excavations, beside providing new information on the topography of the legionary fortress regarding the porta praetoria and the via praetoria, were also significant from a methodological point of view as they allowed the verification of the results of geophysical surveys conducted in the area earlier, thus contributing greatly to the planning and fine-tuning of future measurements. ${ }^{8}$

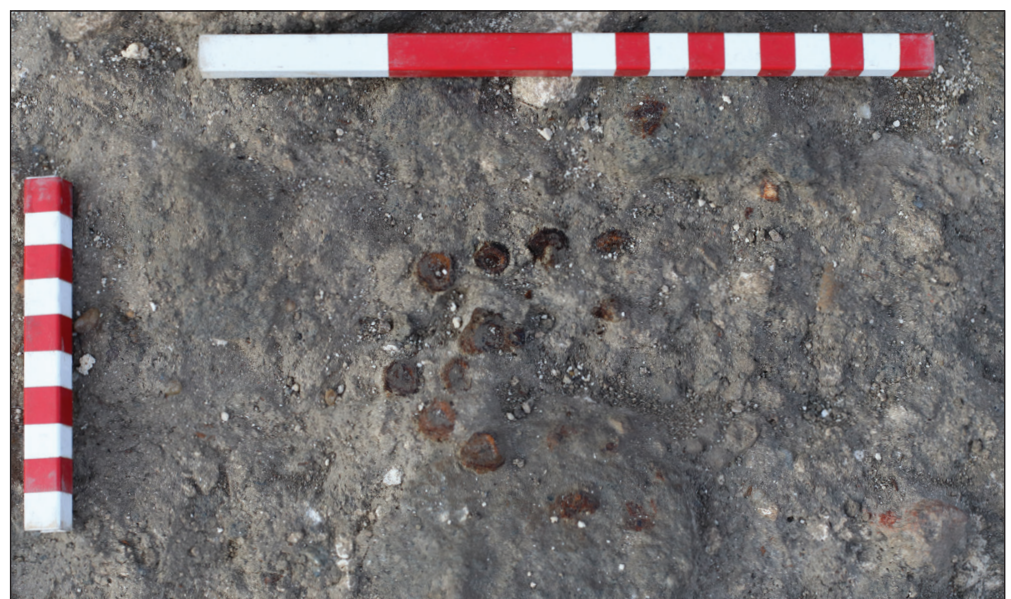

Fig. 9. Iron nails from a caliga (Photo: D. Bartus).

6 On the terminology of antique catapults and other siege engines see CAMPBELL 2011, 689-692.

7 BARTUS 2019.

8 The research on the present paper was supported by the National Research, Development and Innovation Office (NKFI K 119520, NKFI K 134522), Excellence Programme for Higher Education Institutions (FIKP), and the Bolyai+ Postdoctoral Scholarship (ELTE Eötvös Loránd University). 


\section{References}

Aumüller, T. 2002: Die Porta Praetoria und die Befestigung des Legionslagers in Regensburg. Unpublished dissertation. München.

BARkóczi, L. 1951: Brigetio. Dissertationes Pannonicae II/22, Budapest.

BARTUs, D. 2019: Roman bronze gladiators: A new figurine of a murmillo from Brigetio. Dissertationes Archaeologicae 3/7, 177-185. doi: 10.17204/dissarch.2019.177

Bartus, D. - Borhy, L. - Czajlik, Z. 2016: Recent research in the canabae and legionary fortress of Brigetio (2014-2015). In: BeszÉDEs, J. (ed.): Legionary fortress and canabae legionis in Pannonia. Aquincum Nostrum II/7, Budapest.

Bartus, D. - Borhy, L. - Joháczi, Sz. - SzÁmadó, E. 2018a: Short report on the excavations in the legionary fortress of Brigetio (2017-2018). Dissertationes Archaeologicae 3/6, 541-548. doi: 10.17204/dissarch.2018.541

BARtus, D. - Borhy, L. - Sey, N. - SzÁmadó, E. 2018b: Excavations in Brigetio (2012-2016). In: BorHy, L.DévaI, K.-TANKó, K. (eds): Celto - Gallo - Roman. Studies of the MTA-ELTE Research Group for Interdisciplinary Archaeology. Paris, 63-82.

BeChert, T. 1971: Römische Lagertore und ihre Bauinschriften. Bonner Fahrbücher 171, 201-287.

Bishop, M. C. 2012: Handbook to Roman Legionary Fortresses. Barnsley.

Campbell, D. B. 2011: Ancient Catapults: Some Hypotheses Reexamined. Hesperia 80.4, 677-700. doi: 10.2972/hesperia.80.4.0677 
